\title{
EFFECT OF LAND DEGRADATION ON SMALLHOLDERS FARMERS' FOOD SECURITY AND POVERTY STATUS NEXUS LIVELIHOOD DIVERSIFICATION IN NORTH CENTRAL, NIGERIA
}

\author{
Oladimeji, Y. U. ${ }^{1 *}$, Yusuf, O. ${ }^{1}$, Sani, A. A. ${ }^{1}$, Iyanda, A. S. ${ }^{2}$ \\ ${ }^{1}$ Department of Agricultural Economics, Ahmadu Bello University, Zaria-Nigeria \\ ${ }^{2}$ Post Graduate Program, Department of Agricultural Economics, Ahmadu Bello University, Zaria-Nigeria \\ *Correspondence author’s e-mail: yusuf.dimeji@ yahoo.com ; +234803222000
}

\begin{abstract}
The extent of degraded and impoverished lands suitable for agriculture production in Nigeria is highly uncertain and cannot be established without due consideration of current land use and land tenure. The objective of this study was to assess the effect of land degradation on smallholder farmers' food security and poverty status nexus livelihood diversification in north central Nigeria. Primary data with the aid of structured questionnaire was employed to collect the relevant data. A multistage random farming household survey resulted in five Local Government Areas, eleven villages, 330 farmers which were filtered to 142 and 188 land graded farmers (LDF) and non-degraded farmers (NDF) respectively. Descriptive statistics, land degradation perception index, food security and poverty indices, dichotomous regression models were used to achieve the aims of the study. The result indicates that $86.97 \%$ of the sampled farmers identified erosion as the most severe land degradation with perception index of 4.2. Only $12.0 \%$ of LDF were food secured while $40.0 \%$ of NDF were food secured. The poverty status revealed that only $7.04 \%$ of LDF fall under the threshold of 0.00-20.00 category implying non-poor while $46.3 \%$ of NDF fall under the threshold. The results showed that the factors that affected food security and poverty status of LDF had variation from those that affected NDF and where it was the same, not by the same magnitude and direction. The average livelihood security composite index of LDF and NDF were 0.27 and 0.64 respectively implying that NDF had a low diversification as value of one means no diversification. The factors influencing livelihood diversification to non-farm activities by LDF and NDF also differs in magnitudes, coefficients and directions. The results revealed that intercropping and mixed cropping are the most common strategy adopted by farmers in mitigating land degradation with mean index of 4.82. Keywords: Food security, land degraded farmers ( $L D F)$, mitigating strategies, poverty depth
\end{abstract}

http://dx.doi.org/10.21776/ub.agrise.2020.020.3.9

30 May 2020

Accepted 3 July 2020

Available online 29 July 2020

\section{INTRODUCTION}

The special report on climate change and land (SRCCL) and Agenda 21 define land as a physical entity or the terrestrial portion of the biosphere that comprises the natural resources: biota and abiotic resources; the ecological processes, topography, and human settlements and infrastructure that operate within that system (Henry et al., 2018). These components provide a variety of services essential to the maintenance of life-support systems and the productive capacity of the environment together with agriculture. While the development of agriculture underpinned the advancement of civilizations, farming practices led to conversion of forests and grasslands to farmland, and the heavy reliance on domesticated annual grasses for our food production meant that soils started to deteriorate through seasonal mechanical disturbances (Ellis et al., 2019) culminating into land degradation.

Since around 1850, about $35 \%$ of human-caused carbon dioxide emissions to the atmosphere has come 
from land as a combined effect of land degradation and land-use change (Foley, 2005) and about $38 \%$ of the earth's land area has been converted to agriculture (Foley, 2011). The UN convention to combat desertification (CCD), of which Nigeria is a cosigner, recognizes land degradation as a global development and environment issue. Land degradation is defined as the long-term loss of ecosystem function and productivity caused by disturbances from which the land cannot recover unaided (Bai et al., 2008). It is a negative trend in land condition, caused by direct or indirect human-induced processes including anthropogenic climate change, expressed as long-term process (Olsson, 2019) which occurs slowly and cumulatively and has long lasting impacts on rural people who become increasing vulnerable.

The extent of degraded and impoverished lands suitable for agriculture production is highly uncertain and cannot be established without due consideration of current land use and land tenure. Worldwide, it is estimated that nearly two billion hectares (ha) of biologically productive land have been rendered unproductive due to irreversible degradation (Vilanculos, 1994). Of recent, the total area of degraded lands has been estimated at $10-60$ million $\mathrm{km}^{2}$ or about two billion ha (FAO, 2018, Olsson, 2019). The present rate of land degradation is estimated at 5 to 7 million ha per year, suggesting that 0.3 to $0.5 \%$ of the world's arable land is lost annually due to degradation affecting more than 1.5 million people (Vilanculos, 1994, FAO, 2018). According to Abdelfattah, (2009), the world is losing 10 ha of arable land each minute - 5 ha to soil erosion, 3 ha from salinity, and 2 ha by other degradation processes.

The links between poverty and degraded land or the environment interconnected with rural livelihood diversification are influenced by the interaction of socio-economic, demographic and climatic factors. In Nigeria, land tenure systems and limited access to physical assets restricts farmers' ability to engage in improved land use practices which could enhance the productivity of farmers and minimize land degradation. In other words, these factors act as an impediment for environmental conservation and often result in a fundamental process of cumulative causation of poverty, land degradation and under development and results to livelihood diversification from on-farm to off- and non-farm activities. It is germane to mention that studies on poverty in Nigeria have somewhat ignored the nexus between the environment and poverty.

Furthermore, existing policy result in marginal groups (poor) was being relegated to fragile economic environments due to inability to access productive land and lack of technology to improve the productivity of their land. This calls for the need to understand and empirically investigate these links as well as to assess the effect of the land degradation on food security and poverty status nexus livelihood diversification; these are the issues this study dealt with. More importantly, a smallholder farming household with large family size but relatively little and fragmented land will, in the absence of well-functioning land markets, typically apply some labor to their own farm, and hire some labor out for off-farm wage employment in agriculture and non-farm activities. Because individual factors of production face diminishing returns in most productive activities, when individuals or households are not endowed with the ratio that maximizes profits at prevailing shadow prices and there are not welldeveloped asset markets through which they can exchange assets to achieve the optimal mix, livelihood or income diversification becomes the natural response.

Evidence from literature also revealed that there has been an increasing recognition recently that the rural economy is not confined to the agricultural sector, but embraces the broad spectrum of needs of all rural people in other sectors (Davis and Bezemer, 2004; Oladimeji et al., 2015). Household motives for diversification, as well as the opportunities available to them, differ significantly across settings and income groups, suggesting an important distinction between push and pull factors in diversification (Reardon et al., 2007 in Oladimeji et al., 2015). Yet, both factors may be involved in spurring on the process of livelihood diversification. This process has manifested largely in Nigeria where farmers diversify the earning to off- and non-farm activities.

Followed from above, the objective of this study was to assess the effect of land degradation on smallholder farmers' food security and poverty status nexus livelihood diversification in north central, Nigeria. Specifically, the following research questions will be addressed: (i) what is the food security and poverty status of rural farmers whose land was degraded? (ii) what are the effects of land degradation on food security and poverty status of rural farming household heads? (iii) what is livelihood composite index of rural farmers from sources not related to agriculture? (iv) which factors influence the access to income sources outside agriculture? (v) how does farmers cope when their farm lands are degraded? 


\section{METHODOLOGY}

\section{Description of Study Area and Method of Data Collection}

The study was conducted in two States in north central Nigeria: Kwara and Niger. Kwara State is located between $70^{\circ} 45^{\prime}$ and $90^{\circ} 30^{\prime} \mathrm{N}$ Latitude and $20^{\circ} 30^{\prime} \mathrm{E}$ and $60^{\circ} 25^{\prime}$ Longitude at the north central Nigeria with Ilorin as capital occupying a land mass covering about 32,500 square $\mathrm{km}$, a total land size of 3,682,500 ha with majority living in rural areas. The State major ecosystems comprise nearly $90 \%$ of southern guinea and derived savanna zones with scanty of deciduous trees. With an estimated population of about 2.4 million people (NPC, 2006), the State's population and farm families were projected in 2020 to be about $3,624,094$ and 358,880 respectively representing $3.2 \%$ annual growth rate, an average density of 112 persons and agricultural density of 10 persons per sq. $\mathrm{km}$. The mean annual rainfall is $1,524 \mathrm{~mm}$ which spreads within 7 to 9 months in a year with an annual temperature ranges between $14.6{ }^{\circ} \mathrm{C}$ and $36{ }^{\circ} \mathrm{C}$ and average humidity range from $85 \%$ in July to $21 \%$ in January. The vegetation consists largely of a great expanse of arable land and rich fertile soil (Ajao et al., 2014). Niger State is located between Latitude $80^{\circ} 22^{\prime} \mathrm{N}$ and $11^{\circ} 30^{\prime} \mathrm{N}$ and Longitude $30^{\circ} 30^{\prime} \mathrm{N}$ and $70^{\circ} 20^{\prime} \mathrm{E}$ and covers a land area of about 74,244 sq.km, or about $8 \%$ of Nigeria's total land area (NPC, 2006). Niger State has a land mass of about $76,000 \mathrm{sq}$. $\mathrm{km}$. a population of about 3, 950, 249 in 2006 with the State ee population and average density per sq. km projected in 2020 to be about 6057501.368 and 66 respectively.

Primary data was used for this study. Structured questionnaire with the help of trained enumerators under the supervision of the researcher was employed to collect the relevant data. Information collected include socio-economic characteristics of farming households, land degradation indicators to include erosion, deforestation, and topography. An assessment checklist was also used to assess the farm output before land was degraded and after, mitigating strategies adopted by the farmers and land degradation indicators perceived by the crop farmers. Majority of rural farming households in north central Nigeria are smallholding whose production capacity falls between 0.1 and 4.99 ha. Production of arable crops by smallholder farmers in north central Nigeria is achieved through sole or mostly intercropping majorly maize (Zea mays), sorghum (Sorghum bicolor), rice (Oryza sativa), groundnut (Arachis hypogea), cassava (Manihot esculentus) and yam (Discorea Spp).

\section{Sampling Procedure and Sample Size}

A multi-stage random farming household survey was conducted in 4 Local Government Areas (LGAs): Asa, Lafiagi, Moro and Patigi in Kwara State and one LGA (Katcha) in Niger State in 2018/2019 farming season. The choice of the 5 LGAs in the 2 states was because land degradation issues were more predisposed to and pronounced in those areas and has multitudes of tributaries of river Niger overflowing their boundaries with resultant effects of flooding, erosion and waterlogging on farm lands. In the same vein, 2 villages each were purposefully selected from each of the 4 LGAs in Kwara State and 3 villages were selected in Niger State both being areas deeply affected by land degradation. Subsequently, 30 farmers were randomly selected from each of the 11 villages to make a total of 330 in both States. The last stage was a stratified sampling method in selecting affected and nonaffected farmers from sample size. These farmers were filtered to 142 land degraded and 188 non-degraded farmers respectively.

\section{Analytical Techniques}

Descriptive statistics, land degradation perception index, food security and poverty index, and Logit regression models were used to achieve the aims of the study. Food Security Index (FSI) was used to established the food security status of land degraded and non-degraded farmers. A food secured household is one whose per capita monthly food expenditure falls above or is equal to two-third of the mean per capita food expenditure or is equal to or greater than the recommended daily calorie intake of $2600 \mathrm{kcal}$ by Food and Agriculture organisation.

The multidimensional poverty index (MPI) measured the poverty status of the two categories of the farmers. The index was first published in the World Bank (2010) Report and identifies deprivations across three dimensions as depicts in figure 1. A household was identified as multidimensional poor (or 'MPI poor') if they are deprived in at least one third of the weighted indicators with (headcount ratio, $\mathrm{H}$ ), the cutoff for poverty $(\mathrm{k})$ is $33.33 \%$. The intensity of poverty was calculated by multiplying the incidence of poverty by the average intensity of poverty across the poor (MPI $=\mathrm{H} \mathrm{x} \mathrm{A}$ ); this indicated both the share of people in poverty and the degree to which they were deprived. If a person is deprived in $20-33.3 \%$ of the weighted indicators they are considered 'vulnerable to poverty', and if they are deprived in $50 \%$ or more $(\mathrm{k}=$ $50 \%$ ), they are identified as being in 'severe poverty'. 
Table 1. Global Multidimensional Poverty Indicators, * the indicator was modified to composition of food consumed to ensure a balance ration because of difficulty of measuring body mass weight

\begin{tabular}{|c|c|c|}
\hline Dimension & Indicators & What was measured $($ Yes $=1$, No $=0)$ \\
\hline \multirow[t]{2}{*}{$\begin{array}{l}\text { Education } \\
(1 / 3)\end{array}$} & $\begin{array}{l}\text { Years of schooling } \\
(1 / 6)\end{array}$ & $\begin{array}{l}\text { any household member that has not attended at least six } \\
\text { years of schooling }\end{array}$ \\
\hline & $\begin{array}{l}\text { School Attendance } \\
(1 / 6)\end{array}$ & $\begin{array}{l}\text { any school age child up to grade eight that is not attending } \\
\text { school }\end{array}$ \\
\hline \multirow[t]{2}{*}{$\begin{array}{l}\text { Health } \\
(1 / 3)\end{array}$} & Child Mortality(1/6) & $\begin{array}{l}\text { a child has died in the household within the five years prior } \\
\text { to the survey. }\end{array}$ \\
\hline & Nutrition* (1/6) & $\begin{array}{l}\text { a household member is malnourished, as measured by } \\
\text { the body mass index (BMI) for adults (woman ages 15- } \\
49 \text { years) and children }\end{array}$ \\
\hline \multirow{6}{*}{$\begin{array}{l}\text { Standard of } \\
\text { Living }(1 / 3)\end{array}$} & Electricity (1/8) & not having access to electricity. \\
\hline & Sanitation $(1 / 8)$ & not having access to improved sanitation facilities \\
\hline & Water $(1 / 8)$ & $\begin{array}{l}\text { not having access to clean drinking water or through a } \\
\text { source that is located } 30 \text { minutes away or more by walking }\end{array}$ \\
\hline & Floor $(1 / 8)$ & having a home with dirt, sand or dung floor \\
\hline & Cooking fuel $(1 / 8)$ & using "dirty" cooking fuel: dung, wood or charcoal \\
\hline & Asset $(1 / 8)$ & not having at least one asset related to access to \\
\hline
\end{tabular}

Source: Field survey, 2019

The Foster, Greer and Thorbecke (FGT) model poverty index was used to disaggregate poverty status using socio-economic characteristics among the respondents. It is specified as follows:

$\mathrm{P}_{\alpha}=\frac{1}{\mathrm{~N}} \sum_{i=1}^{q}\left[\frac{Z-y_{i}}{Z}\right]^{\alpha}$

(Equation 1 adopted FGT, 1984)

Where: $\mathrm{n}=$ total number of farmers in population, $\mathrm{q}=$ the number of poor farmers, $\mathrm{Z}=$ the poverty line for the household, Yi = Per capita household expenditure for ith farmer whose land was degraded and not degraded, $\alpha=$ poverty aversion parameter and takes on value $0,1,2$. The analysis of the poverty status of the households was decomposed into the three indicators: prevalence of poverty $\left(\mathrm{P}_{0}\right)$, poverty depth $\left(\mathrm{P}_{1}\right)$ and severity of poverty $\left(\mathrm{P}_{2}\right)$.

Logistic regression model was used to estimate the effect of land degradation on food security level and poverty status of the farmers. The model assumes that the probability of the land degraded farmers either being food secured or its poverty status $(P i)$ is expressed as:

$$
P_{i}=\frac{1}{1+\mathrm{e}-\mathrm{Zi}}
$$

$P i$ ranges between zero and one and it is non-linear related to $Z i$. $Z i$ is the stimulus index which ranges from minus infinity to plus infinity. For ease of interpretation of the coefficients, a logistic model could be written in terms of the odds and log of odd. The odds ratio is the ratio of the probability that a household would be food secure $(\mathrm{Pi})$ to the probability of a household not being food secure (1-Pi) or nonpoor or poor. It is expressed as:

$Z i=\ln \frac{\mathrm{Pi}}{1-\mathrm{Pi}}$

To obtain the value of $Z i$, the likelihood of observing the sample were formed by introducing a dichotomous response variable. The explicit logistic model in natural log form is expressed as:

$\operatorname{Ln}\left[\frac{P_{i}}{1-P_{i}}\right]=Z_{i}=\beta o+\beta_{1} X_{1}+\beta_{2} X_{2}+\beta_{3} X_{3}+\beta_{4} X_{4}+\beta_{5} X_{5}+\beta_{6} X_{6}+\beta_{7} X_{7}+\beta_{8} X_{8}+\ldots .+\beta_{11} X_{11}+u$

(Equation 2 through 4 adopted from Idi et al., 2019)

Where: $Y_{i}=($ dependent variable $)$ food security status of the households (food secure $=1$; food insecure $=0$ ), $\mathrm{Y}_{\mathrm{ii}}=$ poverty headcount of the households / (nonpoor $=1$; poor $=0$ ).

$\beta_{0}=$ constant term, $\beta_{\mathrm{i}}-\beta_{8}=$ coefficients, $u_{\mathrm{i}}=$ error term. The independent variables fitted in the two models were operationalized in subsequent results.
The livelihood composite index adopted from Lindenberg, (2002) was used to measure livelihood security of the farmers. The 22 indicators were grouped into three (3) different domains representing livelihood security areas as follows: economic, food security and health security domains. The indicators were standardized since they were measured on different 
scale, then the relevant livelihood security index for the particular domain was constructed by averaging the standardized indicators as follows:

$$
\mathrm{HLS}_{\mathrm{i}}=\frac{\sum \text { Zind } j}{j}
$$

Where $\mathbf{J}$ is the number of indicators used to construct the index. Subsequently the composite overall Livelihood Security (LS) index for the household was constructed by using this formula:

$$
\text { LSCI }=\frac{\sum w i H L S i}{\sum w i}
$$

Where $w$ are the weights determined by the number of indicators used to construct each household LSC index. Weights vary between households because of household level variation in the number of indicators. The median value of 0.5 was used as threshold to determine the level of livelihood security. The land mitigating strategy index ( ${ }_{\mathrm{L}} \mathrm{MSI}$ ) modified from studies of Kyaw (2009) was used to assess the strategies due to land degradation.

\section{RESULT AND DISCUSSION}

Table 2 depicts the rural farmers' knowledge and perception of land degradation. The results revealed that erosion was perceived as the most important indicators of land degradation with frequency percentage of $86.97 \%$ and perception index of 4.2 . Kosmas et al. (2014) opined that it is more meaningful to use indicators than attempt to interpret huge numbers of individual pieces of data. The most useful indicators, however, are those which indicate the potential risk of land degrading and how and scope for remedial action.

Table 2. Farmers' knowledge and perception of land degradation $(n=330)$

\begin{tabular}{lllll}
\hline Degraded indicators & $\mathrm{F}^{*}$ & $\%$ & Perception index & Degraded remarks \\
\hline Erosion & 287 & 86.97 & 4.19 & Extremely \\
Nutrient deficiency & 229 & 69.39 & 3.67 & Severely \\
Soil colour changes & 207 & 62.73 & 2.43 & Moderately \\
Water logging & 173 & 52.42 & 2.28 & Moderately \\
Loss of vegetation & 102 & 30.91 & 1.95 & Slightly degraded \\
Others & 69 & 20.91 & 1.06 & Not /slightly \\
Total / average & 1067 & - & 2.60 & - \\
\hline
\end{tabular}

Note* $^{*}$ Multiple responses allowed

\section{Food Security and Poverty Status}

The food security level and cost implications of land degraded and non-degraded farming households are presented in Table 3. The calorie intake shortfalls are estimated based on the nutritional threshold level of $2260 \mathrm{Kcals} /$ day/adult according to FAO with cost implication of 2.16 United State Dollar (\$) /day/adult equivalent. The level of food insecurity according to Fashina (2019), measures the calorie consumption directly by categorizing the degree of severity of food insecurity. Thus, based on the level of food security, only (17) $11.97 \%$ of land degraded farmers were food secured while 75 farmers (about 40\%) whose land was not degraded were food secured. Although, these category of farmers show zero or minimal evidence of food insecurity, it is evidence from the result that farmers whose land was not degraded are better food secured or less food insecure as only $15.96 \%$ of the total respondents are marginally food insecure or $12.77 \%$ severely food insecure. This is compared to land degraded farmers of which about $88.0 \%$ of the respondents fell to category of food insecure and nearly half of this value $(47.18 \%)$ are severely food insecure.

\begin{tabular}{|c|c|c|c|c|c|c|c|}
\hline \multirow[t]{2}{*}{$\begin{array}{l}\text { Food security } \\
\text { status }\end{array}$} & \multirow{2}{*}{$\begin{array}{c}\text { Calorie consumption } \\
\text { / farmer / day } \\
\text { Kcals }\end{array}$} & \multicolumn{2}{|c|}{$\begin{array}{c}\text { Average cost } \\
\text { implication of Kcal }\end{array}$} & \multicolumn{2}{|c|}{$\begin{array}{l}\text { Degraded } \\
\text { land farmers }\end{array}$} & \multicolumn{2}{|c|}{$\begin{array}{l}\text { Non-degraded } \\
\text { land farmers }\end{array}$} \\
\hline & & $(\mathrm{N})$ & USD, (\$) & $\mathrm{F}$ & $\%$ & $\mathrm{~F}$ & $\%$ \\
\hline Food secure* & Above 2260 & 796.35 & 2.158 & 17 & 11.97 & 75 & 39.89 \\
\hline Marginally fi & Between $1800 \& 2260$ & 729.05 & 1.976 & 25 & 17.61 & 59 & 31.38 \\
\hline Moderately fi & Between $1500 \& 1800$ & 539.63 & 1.462 & 33 & 23.24 & 30 & 15.96 \\
\hline Severely fi & Below 1500 & 469.92 & 1.273 & 67 & 47.18 & 24 & 12.77 \\
\hline Total & & & & 142 & 100 & 188 & 100 \\
\hline
\end{tabular}

Table 3. Food security status and cost implications of land degraded and non-degraded farmers 
The poverty status among the sampled farmers was analyzed using global multidimensional poverty index are presented in Table 4 . The result revealed that only (10) $7.04 \%$ of land degraded farmers fall under the threshold of 0.00-20.00 denoting non-vulnerable or non-poor while $87(46.28 \%)$ of non-degraded farmers fall under this threshold. The result showed that the multidimensional $(28.87 \%)$ and poverty severity $(45.77 \%)$ was very high among land degraded farmers compared to $11.70 \%$ and $21.81 \%$ respectively in nondegraded farmers. The t-statistics of farmers' income or expenditure indicated that there was statistically significant difference between both income and expenditure incurred between the two categories of farmers. It can be inferred that poverty was more prevalent and severe among farmers whose land was degraded compared non-degraded farmers. Furthermore, the result of decomposition of poverty status based on land degraded and non-degraded farmers was reinforcing in figure 1 . The Cumulative Distribution Function (CDF) of farmers whose land was degraded stochastically dominated the CDF of farmers without degradation. This shows that the land degraded farmers will always be poorer than the counterparts within the range of the specified poverty line. This implies that the head count ratio was robust to all possible choices of poverty lines within the specified range.

Table 4: Global multidimensional poverty index of land degraded and non-degraded farmers

\begin{tabular}{|c|c|c|c|c|c|}
\hline \multirow{2}{*}{$\begin{array}{l}\text { Poverty status } \\
\text { Parameters }\end{array}$} & \multirow{2}{*}{$\begin{array}{l}\text { Weighted score aa } \\
\%\end{array}$} & \multicolumn{2}{|c|}{ Land degraded } & \multicolumn{2}{|c|}{ Non-degraded } \\
\hline & & $\mathrm{F}$ & & $\mathrm{F}$ & \\
\hline Non-vulnerable (non-poor) & $0.0-20.00$ & 10 & 7.04 & 87 & 46.28 \\
\hline Vulnerable to poverty & $20.1-33.33$ & 26 & 18.31 & 38 & 20.21 \\
\hline Multidimensional poor (MPI) & $33.34-49.99$ & 41 & 28.87 & 22 & 11.70 \\
\hline Poverty severity & $\geq 50.00$ & 65 & 45.77 & 41 & 21.81 \\
\hline No of observation (n) & 330 & 142 & 100 & 188 & 100 \\
\hline t-statistic by farm income & $6.87 * * *$ & & & & \\
\hline t-test by expenditure ( & $3.21 * * *$ & & & & \\
\hline
\end{tabular}

Source: Field Survey, 2019, Note: $* * *$ denote statistically significant at $1 \%,{ }^{a a}$ adopted the categorization from World Bank (2010) Report

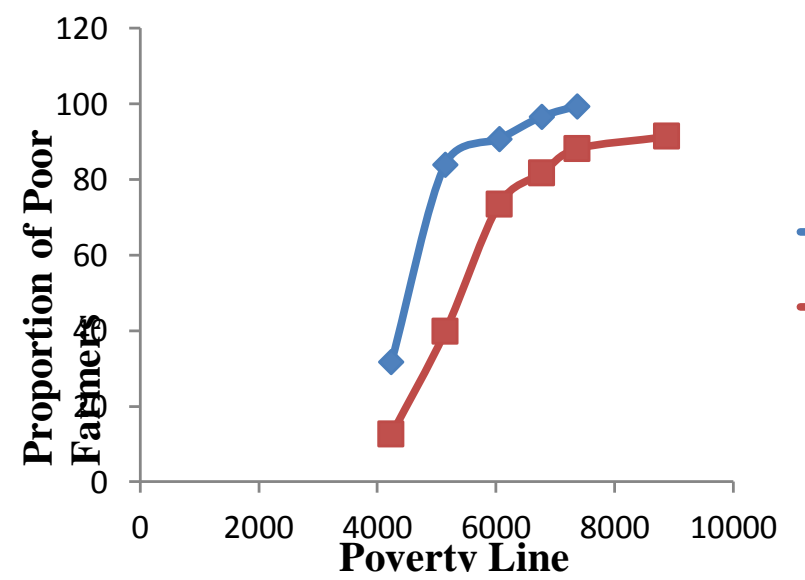

$\multimap$ farmers degraded expenditure

- -farmers non-degraded expenditure

Figure 1. Distribution of dominance analysis by farmers' expenditure

Poverty Profile of Farmers based on Multidimensional Indicators

The results of the poverty indices of selected farmers based on multidimensional indicators are presented in Table 5. Results indicated that poverty incidence, poverty gaps and severity among land degraded and non-degraded farmers showed variance degree of differences and statistically significance in variables ranges. For example, on one hand, age range of 17-30 and greater than 50 years showed statistically significant difference among the two categories and the head count ratio $\left(\mathrm{P}_{0}\right)$ difference of land degraded farmers (0.41) of age range greater than 50 years was higher than non-degraded farmers (0.16). This imply that $41 \%$ of the land degraded farmers were poor compared with non-degraded farmers (16\%). This might be due to the fact that the latter respondents' farm output generating more income or more food secure compared to the former (land degraded farmers). 
Table 5. Identified poverty sub-groups based on socioeconomic status and global multidimensional poverty indicators $(\mathrm{n}=330)$

\begin{tabular}{|c|c|c|c|c|c|c|c|}
\hline \multirow{3}{*}{$\begin{array}{l}\text { Variables } \\
\text { age (years) }\end{array}$} & \multirow[b]{2}{*}{ Range } & \multicolumn{3}{|c|}{ Land degraded farmers } & \multicolumn{3}{|c|}{ Non-land degraded } \\
\hline & & $\mathrm{P}_{0}$ & $P_{1}$ & $\mathrm{P}_{2}$ & $\mathrm{P}_{0}$ & $\mathrm{P}_{1}$ & $\mathrm{P}_{2}$ \\
\hline & $17-30$ & $0.21 * * a$ & 0.09 & 0.05 & 0.25 & 0.03 & 0.008 \\
\hline & $31-50$ & 0.38 & 0.18 & 0.08 & $0.29 * * a$ & 0.02 & 0.009 \\
\hline & $>50$ & $0.41^{\mathrm{ab}}$ & 0.17 & 0.09 & $0.16^{\mathrm{ab}}$ & 0.01 & 0.001 \\
\hline education & $0-6$ & $0.53 * * a$ & 0.17 & 0.09 & $0.39^{\mathrm{ab}}$ & 0.01 & 0.007 \\
\hline \multirow[t]{2}{*}{ (years) } & $7-12$ & 0.36 & 0.14 & 0.02 & 0.11 & 0.04 & 0.002 \\
\hline & $>12$ & $0.11^{\mathrm{ab}}$ & 0.05 & 0.01 & $0.03 * * a$ & 0.00 & 0.000 \\
\hline household & $1-5$ & $0.44 * a$ & 0.13 & 0.05 & $0.27 * a$ & 0.01 & 0.009 \\
\hline \multirow[t]{2}{*}{ size (persons) } & $6-10$ & 0.38 & 0.10 & 0.03 & 0.18 & 0.01 & 0.005 \\
\hline & $>10$ & $0.59^{a b}$ & 0.19 & 0.07 & $0.07^{\mathrm{ab}}$ & 0.01 & 0.001 \\
\hline \multirow[t]{2}{*}{ housing } & mud \& Hut & $0.74 * * a$ & 0.27 & 0.05 & $0.84 * * a$ & 0.17 & 0.003 \\
\hline & cemented & $0.26^{\mathrm{ab}}$ & 0.09 & 0.00 & $0.16^{\mathrm{ab}}$ & 0.09 & 0.000 \\
\hline \multirow[t]{2}{*}{ toilet } & open field & 0.59 & 0.18 & 0.02 & 0.62 & 0.21 & 0.007 \\
\hline & pit toilet & 0.41 & 0.12 & 0.01 & 0.38 & 0.09 & 0.002 \\
\hline source of & local & 0.51 & 0.25 & 0.11 & 0.45 & 0.13 & 0.002 \\
\hline \multirow[t]{2}{*}{ light } & kerosene & $0.33 * a$ & 0.11 & 0.04 & $0.27 * * a$ & 0.09 & 0.001 \\
\hline & electricity & $0.18^{\mathrm{ab}}$ & 0.01 & 0.00 & $0.03^{\mathrm{ab}}$ & 0.00 & 0.000 \\
\hline source of & stream & $0.61 * * a$ & 0.22 & 0.04 & 0.37 & 0.001 & 0.000 \\
\hline \multirow[t]{2}{*}{ water } & well & 0.35 & 0.07 & 0.01 & $0.25 * * a$ & 0.001 & 0.000 \\
\hline & borehole & $0.009^{\mathrm{ab}}$ & 0.00 & 0.00 & $0.001^{\mathrm{ab}}$ & 0.000 & 0.000 \\
\hline energy for & firewood & $0.74 * * a$ & 0.29 & 0.05 & $0.36 * * a$ & 0.09 & 0.000 \\
\hline cooking & kerosene & $0.26^{\mathrm{ab}}$ & 0.08 & 0.00 & $0.15^{\mathrm{ab}}$ & 0.02 & 0.000 \\
\hline
\end{tabular}

Source: Field survey, 2019, $P_{o} ; P_{1} \& P_{2}$ denote the headcount, poverty gap \& squared poverty gap indices respectively; Note: ** \& * denote statistically significant at $5 \& 10 \%$ respectively, ${ }^{a b} \&$ are the two pair of the variables with $t$-value significant.

In line with a priori expectation, the study revealed that farmers with little or no education are more prone to land degradation in the two categories but more pronounced in land degraded farmers with headcount ratio of $\left(\mathrm{P}_{0}=0.53\right)$ as against 0.39 for non-degraded farmers. The results also imply that the average years of schooling of both categories of farmers were inversely related to their poverty status. This is in agreement with earlier studies by Olorunsanya and Omotesho, (2011) that a higher level of educational attainment reduces rural poverty. The incidence of poverty was higher for all farmers, with mud hut housing in land degraded farmers $\left(\mathrm{P}_{0}=0.74\right)$ while the headcount for the non-degrade farmers was reduced to 0.84 . The headcount for the farmers $\left(\mathrm{P}_{0}\right)$ whose house was cemented among degraded farmers was 0.20 as against 0.16 in non-degraded farmers with different level of statistical significance. Therefore, the farmers that occupied accommodation with cemented block and roofed zinc recorded the lowest poor figures for the indices. Farmers that had pit toilet had headcount ratio of 0.59 while those that utilized open field for defecating have headcount of 0.41 in land degraded farmers, 0.62 and 0.38 respectively for non-degraded farmers. In conclusion, there was prevalence of poverty among farmers that utilized open spaces for disposing their faeces, use well water instead of borehole and use firewood instead of either kerosene or electricity as source of light.

\section{Determinants of Food Security and Poverty Status of Farmers}

The Logit model was used in estimating factors that influence food security and poverty status of land degraded farmers in the study area. The estimated coefficients of the Logit model, along with the standard error, $t$-values and marginal effect are presented in Table 5. The log likelihood function was -99.005 , LR $\mathrm{Chi}^{2}$ (11) equal 321.08 and prob. $>\mathrm{chi}^{2}$ was 0.000 which indicates a good fit of the model. The results showed the estimates of the effect of land degradation on food security and poverty status of the affected farmers only. The factors that affect food security status of land degraded farmers had variation from that affecting poverty status and where it does, not by the same magnitude and direction. In food security, the odd ratio otherwise known as coefficients of grazing intensity (1.311), level of tree cut (0.775), frequency of flooding (4.502), farming experience (0.503), farm 
income (14.006) and dependency ratio (-3.009) were found significantly influence food security status of farmers.

Similarly, the results with respect to poverty status revealed that the odd ratio or coefficients of grazing intensity (2.009), conservation practices ($0.657)$, frequency of flooding (-0.690), level of education (-1.008), and farm income (-2.532) were found significantly influence poverty status of the farmers. It suffices to note that the positive coefficients on significant variables of food security imply that as the coefficients of these variables increase, the food security decreases and vice versa. Conversely, the positive coefficients on some poverty variables imply that as these increases, poverty status increases.

Table 6: Logit model on effect of land degradation on food security and poverty status of farmers

\begin{tabular}{|c|c|c|c|c|c|c|}
\hline \multirow[t]{2}{*}{ Variable } & \multicolumn{3}{|c|}{ Food security status } & \multicolumn{3}{|c|}{ Poverty status } \\
\hline & Odds Ratio & SE & $\mathrm{P}>/ / \mathrm{Z} / /$ & Odds Ratio & SE & $\mathrm{P}>/ / \mathrm{Z} / /$ \\
\hline Grazing intensity (dummy) & $1.311 * *$ & 0.074 & 0.001 & $2.009 * * *$ & 0.032 & 0.000 \\
\hline Level of trees cut (no) & $0.775^{* *}$ & 0.002 & 0.000 & $7.032 * * *$ & 0.229 & 0.000 \\
\hline Conservation practices (no) & 3.241 & 0.135 & 1.074 & $-0.657 *$ & 0.036 & 0.070 \\
\hline Farm size (ha) & -0.308 & 0.276 & 0.874 & 1.005 & 0.942 & 0.216 \\
\hline Frequency of flooding (no) & $4.502 *$ & 0.098 & 0.038 & $0.690 * *$ & 0.328 & 0.069 \\
\hline Age (years) & 0.197 & 0.015 & 0.897 & 0.107 & 0.619 & 0.229 \\
\hline Level of education (years) & -1.096 & 0.184 & 0.865 & $-1.008^{*}$ & 0.301 & 0.062 \\
\hline Farming experience (years) & $0.503 * *$ & 0.167 & 0.001 & 0.009 & 0.311 & 0.210 \\
\hline 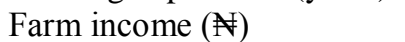 & $14.006 * *$ & 0.003 & 0.025 & $-2.532 * * *$ & 0.062 & 0.000 \\
\hline Dependency ratio (index) & $-3.009 * *$ & 0.052 & 0.000 & -0.008 & 0.207 & 0.643 \\
\hline Non-farm income ( & -0.004 & 0.059 & 0.792 & 0.005 & 0.012 & 0.311 \\
\hline Intercept & $-0.172 * *$ & 0.199 & 0.002 & $1.119 *$ & 0.806 & 0.092 \\
\hline \multicolumn{7}{|l|}{ Diagnostic statistics } \\
\hline No. of observation & 142 & & & 142 & & \\
\hline LR $\operatorname{chi}^{2}(11)$ & 287.167 & & & 321.08 & & \\
\hline Log likelihood function & -109.023 & & & -99.005 & & \\
\hline \multicolumn{7}{|l|}{ Chi square $(\chi 2)$} \\
\hline Pseudo $\mathrm{R}^{2}$ & 0.213 & & & 0.308 & & \\
\hline Probability $>\mathrm{Chi}^{2}$ & 0.000 & & & 0.000 & & \\
\hline
\end{tabular}

Source: field survey, 2018 / 2019; Note: no denote number; Note: ** \&* denote statistically significant at $5 \& 10$ $\%$ respectively,

\section{Livelihood Security of Land degraded and Non- degraded Farmers}

Figure 2 depicts level of livelihood security of land degraded and non-degraded farmers with the average composite indices of 0.27 and 0.64 respectively. An average value of 0.64 implies that non-degraded farmers had a low diversification as value of one means no diversification. Conversely, land degraded farmers with average value of 0.27 and about $75.36 \%$ with composite index of $0.01-0.50$ shows that diversification is very high probably due to their degraded farms. Hence these farmers could not rely solely on farming and required access to income sources outside agriculture activities.
Table 7 demonstrates the factors influencing livelihood diversification to off- and non-farm by land degraded and non-degraded farmers. The negative coefficients on remittance and gifts (-0.087), level of degradation (-0.007) and household size (-0.407) imply that these variables will increase land degradation. A negative coefficient on level of degradation means low level output and tendency to diversify outside agriculture. Furthermore, variables such as level of education, farm size and cooperative membership were the factors statistically significant and all have positive influence in determining income diversification towards agricultural activities among non-degrade farmers. 


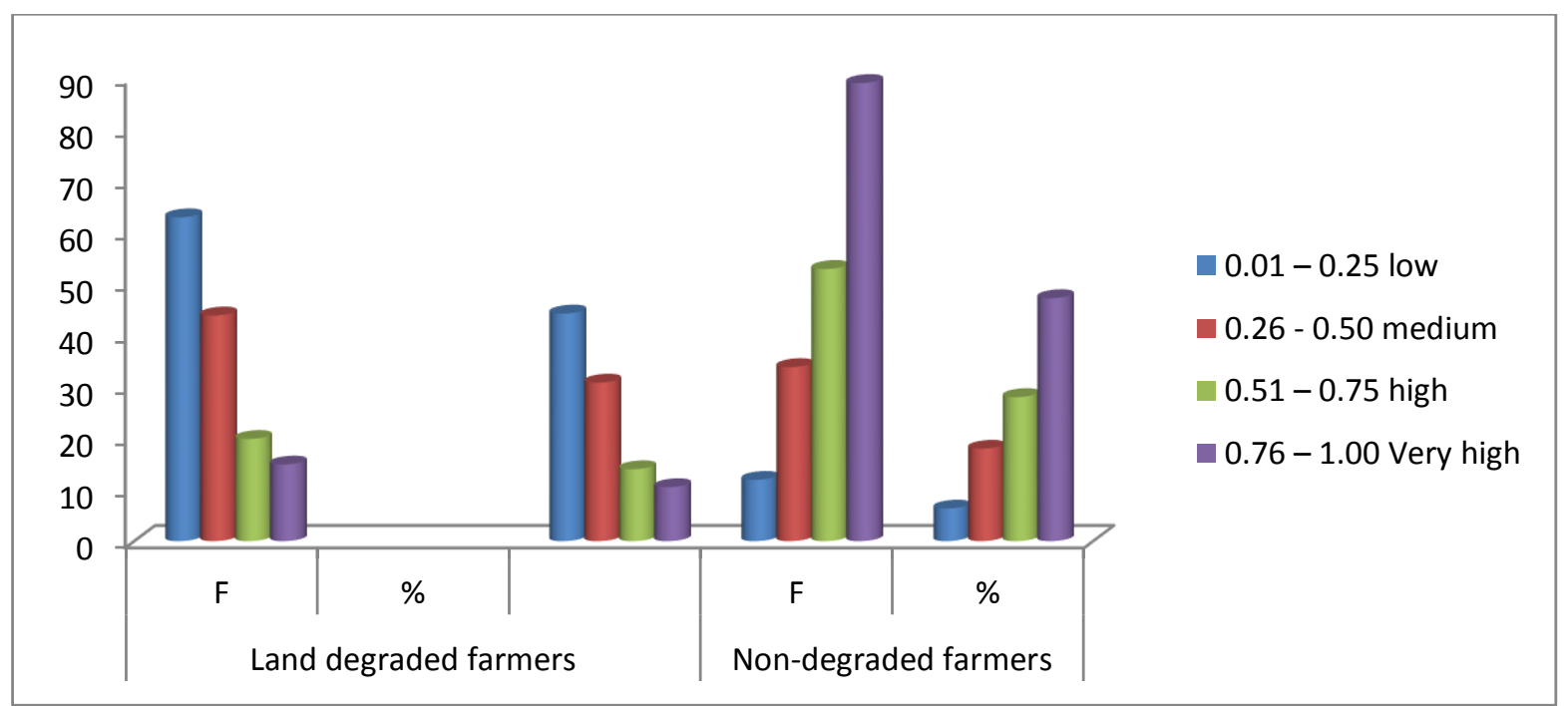

Figure 2: Level of livelihood security using the mean value of the composite indices

Table 7: Factors influencing farmers' livelihood diversification to non-farm activities

\begin{tabular}{lllrllr}
\hline \multicolumn{1}{c}{ Variables } & \multicolumn{3}{c}{ Land degraded farmers } & \multicolumn{3}{c}{ Non-degraded farmers } \\
\hline Age (years) & $\beta$ & SE & t-value & $\beta$ & SE & t-value \\
Non-farm income (N) & $0.503^{* * *}$ & 0.107 & 4.70 & 0.123 & 0.135 & 0.91 \\
Remittance and gifts (N) & $0.219^{* * *}$ & 0.075 & 2.92 & -0.108 & 0.099 & -1.09 \\
Land degradation (dummy) & $-0.087^{* * *}$ & 0.023 & -3.78 & $-0.340^{* * *}$ & 0.127 & -2.68 \\
Level of education (years) & $-0.007^{* * *}$ & 0.002 & -3.5 & - & - & \\
Farm size (ha) & 0.121 & 0.105 & -1.15 & $0.349 * * *$ & 0.112 & 3.12 \\
Household size (number) & 0.004 & 0.005 & 0.8 & $0.107 *$ & 0.056 & 1.91 \\
Credit accessed (N) & $-0.407 * * *$ & 0.069 & -5.90 & $0.324 * * *$ & 0.099 & 3.27 \\
Per capital expenditure (N) & 0.054 & 0.065 & -0.83 & $-0.347 * * *$ & 0.104 & -3.34 \\
Constant & $0.143^{*}$ & 0.075 & 1.91 & $0.521^{*}$ & 0.266 & 1.96 \\
No of observation & $-0.122^{* * *}$ & 0.049 & 2.49 & $-0.108 * * *$ & 0.009 & -12.00 \\
LRChi (9), (8) & 142 & & & 188 & & \\
Log likelihood & 197.06 & & & 287.98 & & \\
$\mathrm{R}^{-2}$ & 68.54 & & & 108.04 & & \\
Prob. > chi square & 0.287 & & & 0.352 & & \\
Var (e. level) & 0.000 & & & 0.000 & & \\
\hline
\end{tabular}

Source: Field survey, $2019 * ; * * ; * *$ implies significant at 10\%, 5\% and 1\% respectively

\section{Land mitigating strategies adopt by the farmers in the study area}

Table 8 depicts the distribution of strategies adopt by the farmers in mitigating land degradation. The results revealed that intercropping and mixed cropping are the most common strategy adopted by farmers in mitigating land degradation with mean of 4.82. This was followed by plant trees such as Jatropha curcas at the edge or boundary of their farm to prevent rill and possible gully which usually occur on a sloping surface and where runoff is prevalent because of land use and lack of vegetation. 
Table 8. Mitigating strategies employed by the farmers to curb land degradation ( $\mathrm{n}=330-)$

\begin{tabular}{|c|c|c|c|c|c|c|c|}
\hline Strategies & $\begin{array}{l}\text { V. } \\
\text { often } \\
(5)\end{array}$ & $\begin{array}{l}\text { Often } \\
\text { (4) }\end{array}$ & $\begin{array}{l}\text { moderately } \\
\text { (3) }\end{array}$ & $\begin{array}{l}\text { Rarely } \\
\text { (2) }\end{array}$ & $\begin{array}{l}\text { Not } \\
\text { used } \\
\text { (1) }\end{array}$ & $\begin{array}{l}\text { Weighted } \\
\text { score }\end{array}$ & $\begin{array}{l}\text { Mean } \\
\text { index }\end{array}$ \\
\hline $\begin{array}{l}\text { Inter / mixed cropping / crop } \\
\text { rotation }\end{array}$ & 665 & 320 & 201 & 76 & 12 & 1592 & 4.82 \\
\hline Plant tree /grass at edge & 520 & 288 & 216 & 104 & 30 & 1458 & 4.42 \\
\hline Organic manure & 435 & 272 & 183 & 128 & 50 & 1348 & 4.08 \\
\hline Cover cropping & 270 & 244 & 216 & 168 & 59 & 1228 & 3.72 \\
\hline $\begin{array}{l}\text { Tillage practices } \\
\text { waterways, contour, }\end{array}$ & 240 & 256 & 207 & 180 & 59 & 1213 & 3.68 \\
\hline mulching & 160 & 196 & 231 & 188 & 78 & 1105 & 3.35 \\
\hline Land fallowing & 105 & 160 & 156 & 186 & 124 & 937 & 2.84 \\
\hline Climate change forecast & 70 & 76 & 123 & 174 & 169 & 773 & 2.34 \\
\hline
\end{tabular}

Source: Field survey, 2019

\section{CONCLUSION AND RECOMMENDATIONS}

The study examined assesses the effect of land degradation on smallholder farmers' food security and poverty status nexus livelihood diversification in Kwara and Niger States, north central, Nigeria. Results indicated that poverty incidence, poverty gaps and severity among land degraded and non-degraded farmers showed variance degree of differences and statistically significance in variables ranges. The factors that affect food security and poverty status of land degraded farmers had variation from that affecting poverty status and where it does, not by the same magnitude and direction. Mixed cropping, tree planting and organic manure were recommended to minimize land degradation.

\section{REFERENCES}

Abdelfattah, M. A. (2009), Land degradation indicators and management options in the desert environment of Abu Dhabi, United Arab Emirates. Soil Survey Horizons, 50, 3-10.

Ajao, A. M., Oladimeji, Y. U., Babatunde, S. K. and Obembe, A. (2014). Morphological characteristics of Apis mellifera $L$. (Hymenoptera: Apidae) in Kwara State, Nigeria. International Journal of Agricultural Science, 4(4), 171-175.

Bai, Z. G., Dent, D. L., Olsson, L., and Schaepman, M.E. (2008). Global assessment of land degradation and improvement 1: identification by remote sensing. Report 2008/01, FAO/ISRIC - Rome / Wageningen.

Davis, J. and Bezemer, D. (2004). The development of the rural non-farm economy in developing countries and transition economies: key emerging and conceptual issues. Chatham, UK: NRI.

Ellis, P.W. (2019): Reduced-impact logging for climate change mitigation (RIL-C) can halve selective logging emissions from tropical forests. Forest Ecology Managt., 438, 255-266,

Food and Agriculture Organisation, (2018). Land and Water. http//www/fao.org land \& water.

Foley, J. A. (2005). Global consequences of land use. Science, 309, 570-574,

Foley, J. A. (2011). Solutions for a cultivated planet. Nature, $\quad 478, \quad 337-342$, doi:10.1038/nature10452.

Foster, J. J., Greer, J. and Thorbecke, E. (1984). A class of decomposable poverty measures. Econometrica, 52, 761-765.

Henry, B., Murphy, B. and Cowie, A. (2018). Sustainable Land Management for Environmental Benefits and Food Security. A synthesis report for the GEF. Washington DC, USA, 127 pp.

Fashina, A. O. (2019). Analysis of Food Security Status of Ginger Farming Households of Kaduna State, Nigeria: a Multidimensional Approach. An Unpublished Masters Dissertation Submitted to School of Postgraduate Studies, Ahmadu Bello University, Zaria, Nigeria. 130pp.

Idi, A. S. Damisa, M. A., Ahmed, B., Edekhogregor, O. I. and Oladimeji, Y. U. (2019). Macrocredit utilization and as impact on farmers maize output and household food security in 
Kaduna State, Nigeria. Journal of Agric. and Environment, 15(1), 19-31.

Kosmas, C., Kairis, Ch., Karavitis, Ch., and Christian P. (2014). Evaluation and selection of indicators for land degradation and desertification monitoring: methodological approach. Environmental Management, 54(5), 951-970.

Kyaw, D. (2009). Rural households, food security and coping strategies to food insecurity in Myammar. Asian Journal of Agricultural Research, 5, 51-54.

Lindenberg, M. (2002). Measuring household livelihood security at the family and community level in the developing world. World Development, 30(2), 301-318.

National Population Commission, NPC, (2006). Population Census of the Federal Republic of Nigeria. Analytical Report at the National Population Commission, Abuja, Nigeria.

Oladimeji, Y. U., Abdulsalam, Z. and Abdullahi, A. N. (2015). Determinants of participation of rural farm households in non-farm activities in kwara state, Nigeria: a paradigm of poverty alleviation. Ethiopian J. of Environmental Studies and Management, 8(6), 635 - 649.

Olorunsanya, E. O. and Omotesho, O. A. (2011). A gender analysis of poverty profile of rural farming households in North Central, Nigeria. Int. J. of Agric. Econs. and Rural Dev, 4(2), 11-27.

Olsson, L. (2019). Land Degradation. In: Climate Change and Land: an IPCC special report on climate change, desertification, land degradation, sustainable land management, food security, and greenhouse gas fluxes in terrestrial ecosystems [P.R. Shukla et al., (eds.)].

Vilanculos, M. F. (1994). Interlinkages of soil and land use using remote sensing and GIS, a case study of the Ping Valley, Chiang Mai, Thailand. MSc Thesis. ITC, Enschede, the Netherlands.

World Bank, (2010). African Development Indicators. New York, Oxford University Press. 
This page is intentionally left blank 